Ankara Üniversitesi Türk Inkılâp Tarihi Enstitüsü Atatürk Yolu Dergisi

S 27-28, Mayı-Kasım 2001, s. 321-333

\title{
Türk İnkılâp Tarihi Enstitüsü (1933)
}

\author{
Yard. Doç. Dr. Mustafa ORAL
}

\section{ÖZET}

Türk Inkılâp Tarihi Enstitüsü, Atatürk önderliğindeki Inkılâp hareketinin çağdaş biçimde incelenmesi ve genç kuşaklara öğretilmesi amacına yönelik olarak, üniversite reformu kapsamında ve Cumhuriyet'in onuncu yıldönümünde (1933), İstanbul Universitesi bünyesinde kurulmuş bir araştırma ve ögretim merkezidir. Yakınçă̆ Türkiye Tarihi araştırmaları alanında modern bir araştırma merkezi olması planlanan bu enstitüde istihdam edilen öğretim görevlileri, Kurtuluş hareketinin ve Cumhuriyet inkılâplarının içinde yer almış tarihî şahsiyetlerdir. Enstitünün kuruluşuna, Rejime sahip çıkacak gençler yetiştirmek ve Inkılâp ideolojisini etraflı şekilde işlemek düşüncesi yol açmıştır. Bu makalede, Türkiye'de devrim tarihi araştırmalarının ve öğretiminin başlangıç aşaması açıklanmaya çalışılmıştır.

Anahtar Kelimeler: Atatürk, İstanbul Üniversitesi, Türk Devrimi, Türk Inkılâp Tarihi Enstitüsü.

\begin{abstract}
The Institute of Turkish Revolutionary History is a research and educating center that was founded in the 10th anniversary of Turkish Republic (1933) in the body of İstanbul University for scrutinizing the revolutionary movement in the leadership of Atatürk in contemporary level and teaching to the youth. The lecturers, whose are historical personalities and participating in the Independence movement and the revolutions of the Republic, are hired in this institute that was planned the contemporary center in the researches of the near age of Turkish History. It is paved the way for the foundation of the Institute to discuss the revolutionary ideology and to bring up the youngs to claim the regime. In this article, it is tried to be explained the beginning stages of revolutionary history and its educating in Turkey.
\end{abstract}

Key Words: Atatür, Turkish Revolution, The Institute of Turkish Revolutionary History.

•Akdeniz Üniversitesi Fen-Edebiyat Fakültesi Tarih Bölümü (mustoral@ akdeniz.edu.tr). 
Türkiye'de tarih anlayışı, tarih yazımı ve tarih öğretimi üzerindeki araştırmalar gittikçe yoğunluk kazanan bir şekilde ilgi ve alâkaya mahzar olmaktadır. Bu alandaki çalıșmalar Yakınçağ kültür ve düşünce tarihimizin aydınlatılması açısından oldukça önemlidir. Bugünkü kültür hayatımızın belirleyici unsurları arasında üniversite kurumu kuşkusuz önemli bir konuma sahiptir. Türkiye'de modern anlamda üniversitenin kuruluşunun gerçekleştiği cumhuriyetin onuncu yılında, bir İnkılâp Enstitüsü kurulmuş ve İnkılâp Tarihi Dersleri verilmeye başlamıştır. Bu enstitü bünyesinde ve İnkılâbın yapıcıları tarafından verilen İnkılâp Dersleri, devletine sahip çıkan bir cumhuriyet nesli yetiştirmek, cumhuriyet rejiminin güvenliğini sağlamak ve geleceğini teminat altına almak, çabaları açısından önemli bir başlangıç olmanın yanısıra bu alanda kurumsallaşmış bir gelenek de yaratmıştır.

İstanbul Üniversitesi Türk İnkılâp Tarihi Enstitüsü, 1933 Üniversite Reformu sırasında kurulmuştur. Enstitünün kuruluşuna yol açan fikirler ise Cumhuriyetin ilk yıllarında ortaya çıkmıştır. Mustafa Kemal Atatürk, 7 Nisan 1924'te yaptığı bir açıklamada, "İstanbul'u terkettiğim güne takaddüm eden vaziyetleri ayrı bir safha olmak üzere, o günden bu güne kadar cereyan eden vakayiin mazbut ve mahfuz olan vesaikini tasnif etmek suretiyle hatıratımı yazmak niyetindeyim" diyordu. Bunun nedenini "Nesl-i âti için, Türkiye Cumhuriyeti tarihi için bir vazife de telakki ediyorum" șeklinde açıklayan Atatürk, millî tarih yazımı açısından, hatıraların kaleme alınarak yayınlanmasına gereksinimi olduğunu belirtiyor ve şöyle devam ediyordu': "Bizim şimdiye kadar doğru bir tarih-i milliye malik olamayışımızın sebebi tarihlerimizin, hakiki karilerin vesaika istinat etmekten ziyade, ya birtakım meddahların veya birtakım hodgâmların hakikat ve mantıktan âri sözlerinden başka memba bulamamak bedbahtlığıdır." Atatürk, 1927'de hazırladığ "Nutuk" adlı eserinde ise, "Maksadım, inkılâbımızın incelenmesinde tarihe yardımcı olmaktır." diyordu.

Türkiye'de İnkılâp Tarihi dersleri ilk kez Ankara Hukuk Mektebi'nde okutulmuştur. Ankara Hukuk Mektebi'nin kuruluşu çalışmaları sırasında okulun müfredat programına "İhtilâller Tarihi" dersi konulmuştu. Bu dersi, dönemin Adalet Vekili Mahmut Esat Bozkurt'un okutmasina karar verilmişti. Bu dersin müfredat programına konulması, Hukuk Mektebi'nin 15 Eylül 1925 tarihli ilk kurucular kurulu toplantısında Adliye Vekili Mahmut Esat (Bey) Bozkurt ile Devletler Hukuku Müderrisi Cemil (Bey) Bilsel arasındaki görüşmede kararlaştırılmıştı. Bu derslerin, esas hukukun bir kısmını oluşturduğu ve hukuk ile tarih arasındaki yakın ilişkiler nedeniyle hukuk öğrencilerine yararlı olacağı düşünülmüștü. Bu derslerle, modern bir

\footnotetext{
'Atatürk'ün Söylev ve Demeçleri, C.III, Ankara, Atatürk Araştırma Merkezi (AAM) Yayınları, 1997, s.99.

${ }^{2}$ Kemal Atatürk. Nutuk (1919-1927). Ankara, AAM Yayınları, 1997, s.297.
} 
hukuk ekolü yaratılmak istenmiștir ${ }^{3}$. Şunu da belirtelim ki, Mahmut Esat'ın İhtilâller Tarihi dersleri radyoyla da yayınlanmıştır. Bu, son derece anlamlıdır; çünkü, İnkılâbın halkçılık boyutu vurgulanmış oluyordu. Kemal Atatürk, 5 Kasım 1925 'te Ankara Hukuk Mektebi'nin açılışında yaptığı konuşmada, Türk İnkılâbı'nın o vakte kadarki gelişimini ana hatlarıyla belirtmiș ve ondan sonraki yönelimini şöyle açıklamıștır": "Şimdi vücuda gelen bu büyük eserin zihniyetini, ihtiyacatını tatmin edecek yeni esasatı hukukiyeyi ve yeni erbabı hukuku vücuda getirmek için teşebbüs almağa zaman gelmiştir."

Başka ülkelerde ise, örneğin Fransa'da Devrim Tarihi derslerinin ve bununla ilgili kutlamaların uzun bir geçmiși bulunuyordu. Fransa'da $1880^{\prime}$ den itibaren, Fransız Devrimi'nin gerçekleştiğ tarih olarak kabul edilen 14 Temmuz günü bayram olarak ilân edilmişti. Bundan birkaç yıl sonra Sorbonne Üniversitesi'nde bir Devrim Tarihi kürsüsü kurulmuştu. Ancak bu vakitte Fransız Devrimi üzerine tarih yazımının yarım yüzyıllık bir mazisi bulunuyordu'. Sovyet Rusya'da ise 1917 Bolşevik Devrimi'nin halka tanıtılması amacını güden devrim müzeleri kurulmuştu. Bu müze, her sınıftan insana Bolşevik Devrimi'ni tanıtmak amacına matuftu. Bunun bir benzerinin, aynı zamanda Yakınçağ Türkiye Tarihi incelemeleri açısından önemli bir araştırma merkezi şeklinde bizde de açılması zarurî görülüyordu ${ }^{6}$. Bizde ise bu paralelde 1927 'de Etnoğrafya Müzesi bünyesinde bir İnkılâp Şubesi kurulmak istenmiş, bunun için ciddi anlamda hazırlıklar bile yapılmıștı. Bu hazırlıklardan en önemlisi, İnkılâp Şubesi'nde sergilemek amacıyla toplanacak eserlerin niteliğine ilişkin çalışmadır ${ }^{7}$. Bu müze uzun bir hazırlıktan sonra ancak 1942 yılında faaliyete geçirilebilen ve bugunkü Ankara Üniversitesi Türk İnkılâp Tarihi Enstitüsü bünyesindeki Devrim Tarihi Müzesi'dir.

Türkiye'de ise Cumhuriyetin onuncu yılına gelindiğinde, İstanbul Üniversitesi bünyesinde Türk İnkılâbı Enstitüsü adı altında bir kuruluş vücuda getirildi. Bundan önce de 19 Nisan 1924 tarih ve 628 sayılı kanun ile Cumhuriyetin kuruluş tarihi milli bayram ilân olarak edilmişti. Bununla

${ }^{3}$ Ahmet Mumcu, Ankara Adliye Hukuk Mektebinden Ankara Üniversitesi Hukuk Fakültesine (1925-1975), Ankara, A.Ü Hukuk Fakültesi Yayınları, 1977, s.67-68. M. E. Bozkurt, Ankara Hukuk Mektebi'nde İhtilâller Tarihi'ni 30 Ocak 1926 Cuma günü saat 17.00 'de okutmaya başlamıştır. "Hukuk Mektebi'nde İhtilâller Tarihi", Hakimiyet-i Milliye, 28 Kanunusani 1926, s.1.

${ }^{4}$ Atatürk'ün Söylev ve Demeçleri, C.II, Ankara, AAM Yayınları; 1997, s.249-250.

${ }^{5}$ Bu konuda geniş bilgi için bkz: Server Tanilli, Dünyayı Değiştiren On Yıl: Fransız Devrimi Üstüne (1789-1799), 2. Baskı, İstanbul, Say Yayınlanı, 1989, s.209 vd.

${ }^{6}$ Köprülüzade Mehmet Fuat, "Inkılap Terbiyesi”, Hayat, C.II/29 (16 Haziran 1927), s.4142.

${ }^{7}$ Bu eserlerde aranan nitelikler için bkz: Türkiye Cumhuriyeti Maarif Vekâleti Millî Talim ve Terbiye Dairesi, Etnografya Müzesi Inkılâp Şubesine Kabul Olunacak Asâra Dair, İstanbul. Devlet Matbaası. 1928. 
birlikte, İnkılâp Tarihi derslerinin öğretimi, 1929 ekonomik buhranı ile onu izleyen 1930 demokrasi tecrübesinin akabinde gündeme gelmiştir. Atatürk, Serbest Cumhuriyet Fırkası'nın kapandığı gün, üç ay süren (17 Kasım 19306 Ocak 1931, 26 Ocak-2 Mart 1931) bir yurt gezisine çıkmıştı. Bu inceleme gezisinde Cumhuriyet rejiminin aleyhindeki hareketlerin önlenmesi ve Cumhuriyet yönetiminin pekiştirilmesi amacına yönelik notlar alan ve bunları hükümete sunan Atatürk, bu yönde alınması gereken önlemlerden birini şöyle not etmiştir": "Bir cumhuriyeti ve rejimi koruma kanunu neşredilmelidir. Bu kanunda, bizzat Cumhuriyet aleyhinde olduğu gibi onun temellerini teşkil eden inkılâp kanunları aleyhinde fiilen harekete teşvik veyahut bu bapta söz ve yazı ile telkin, ağır ceza müeyyidelerine bağlanmalıdır."

Bu inceleme gezisi sırasında Atatürk, Şubat 1931'de Antalya Lisesi'ni ziyaretinde bir sınıfa girmiş ve dersin Fransız İnkılâbı olduğunu öğrenince, orada bulunanlara, "1789 Fransız İnkılâbı ile 1919 Türk İnkılâbı arasında ruh ve düşünüş benzerliği nedir, bu inkılâplar arasında ne gibi benzeyiş ve ayrılıklar vardır?" sorusunu yöneltmiştir. Bir öğrencinin bu soruyu "1919 Türk İnkılâbı"nın önderinin açıklamasının öğretici olacağını söylemesi üzerine, Atatürk, şu açıklamalarının not edilmesini istemiştir": "Bu iki inkılâbın ruh ve düşünüş birliği ve benzerliği: Açlık ve sefalet içinde yaşıyan, şuurlu bir milletin sefahat ve ihtişam içinde yaşıyan şaşırmış bir idareye boyun eğmemesi ve onu boğmasıdır."

Ahmet Ağaoğlu, Türk İnkılâbı'nın en önemli tarihsel belgesi saydığı Misak-1 Millı̂'yi, İngilizlerin 1215 Magna Charte Libertum'u ve Fransızların 1789 Hukuk-ı Beşer Beyannamesi ile karşılaştırarak, Türklerin 1920 tarihli Misak-1 Millîsi ile Doğu dünyasında yeni bir hayat dönemi açıldığını belirtiyordu ${ }^{10}$. Aynı sıralarda "Kadro" dergisinde, İnkılâbın kuramsal boyutuna ilişkin, özellikle Şevket Süreyya Aydemir imzalı makaleler yayınlanıyordu. Kadroculardan Ş. S. Aydemir, iki kısımdan oluşan ve 1932'de kitap halinde çıkan "İnkılap ve Kadro" adlı eserinin bazı kısımlarını 1931 'de "Hakimiyet-i Milliye" gazetesinde yayınlamıştı. Bu eserin "İnkılap" kısmı 15 Ocak 1931'de Türk Ocakları merkez binasında verilen bir konferansın genişletilmiş șeklidir. "Kadro" kısmı ise CHF'nin isteği üzerine bir muhtıra olarak kaleme alınmış ve daha sonra geliştirilerek "Hakimiyet-i Milliye" gazetesinde tefrika edilmiştir. Bu iki kısım, yöneticilerin değerlendirmeleri de dikkate alınarak, 1932'de bir kitap halinde yayınlanmıştır. "İnkılap ve Kadro"nun konusu, Aydemir'in ifadesiyle,

\footnotetext{
${ }^{8}$ Atatürk'ün Seyahat Notları (1930-1931), yay, haz. Gürbüz Tüfekçi, İstanbul, Kaynak Yayınları, 1998, s.84.

${ }^{9}$ M. Cemal Altanay, "Türk ve Fransız İnkılâbları", Atatürk'e Ait Hattralar, der. Ahmet Hidayet Recl, Istanbul, Cumhuriyet Matbaası, 1949, s.155-156.

${ }^{10}$ Ahmet Ağaoğlu, "Millî Misak'ın Tarihî Kıymeti”, Ülkü, Nu.I/I (Şubat 1933), s.41 vd.
} 
İnkılâbın düşünsel esaslarının "belirli bir görüş" (tarihsel materyalizm) açısından incelenmesidir ${ }^{11}$.

Cumhuriyetin onuncu yıldönümünde Türk İnkılâbı'nın düşünsel ve kuramsal boyutları konusunda yapılan araştırmalarda dikkate değer gelişmeler olmuştur. Burhan Asaf Belge, Kasım 1932'de yayınlanan bir makalesinde, Türk İnkılâbı'nı incelemek ve tanıtmak amacıyla bir "İnkılâp Kütüphanesi" kurulmasını istiyor ve "1933 sonuna kadar Türk İnkılâbı hakkında hiç olmazsa 100 adet eser yazılmalıdır" ${ }^{2}$ temennisinde bulunuyordu. Fakat, "Kadro" dergisinin Türk İnkılâbı'nı tarihsel materyalizm düşüncesi temelinde açıklamaya ve buradan hareketle kuramsal temellere oturtmaya çalışması, resmi çevrelerce pek de benimsenen bir yaklaşım değildir. Nitekim, "Kadro"nun Ocak 1935'te son sayısını yayınlanması ve yazar kadrosunun dağılması ve derginin imtiyaz sahibi Yakup Kadri'nin söz konusu dergiyi çıkarmak üzere olduğu sıralarda CHF Genel Sekreteri Recep Peker'in tutumu buna kanttır. Recep Peker, o sıralarda Yakup Kadri'ye, "Parti namına neşriyatta bulunmak hakkını kimden alıyorsunuz? Bir fikir mecmuası çıkarmak lâzım gelirse onu ancak biz çıkarırız ve zaten çıkarmak üzereyiz de..." demiştir ${ }^{13}$. Üstü kapalı şekilde belirtilen bu mecmua, Şubat 1933 'ten itibaren yayın hayatına giren ve Halkevleri merkez yayın organı olan "Ülkü" dergisidir.

Türk İnkılâbı Enstitüsü'nün kurulması yönünde ilk çalışmalar, Darülfünûn Reformu sırasında Maarif Vekili Reşit Galip zamanında başlatılmıştır. Reşit Galip, Birinci Türk Tarih Kongresi'nde Türk Tarih Tezi'ni sunumuyla ve Zeki Velidi Togan ile tartışmasıyla dikkat çekmiş ve Darülfünun'un bilimsel şahsiyetinin yetersiz olduğunu ifade etmişti. Falih Rıfkı Atay, kongreden sonra Darülfünun'un Türk İnkılâbı'na karşı tutumunu şöyle açılılıordu ${ }^{14}$ : "Darülfünunda Türk İnkılâbı için en iyi yazılmış esere verilmek üzere 5000 liralık bir mükâfatın senelerden beri durmakta olduğunu biliriz. Bu mükâfatın hiç kimseye verilmemiş olması, fikir hayatının pek durgun olduğu hükmünü verdirebilir. Fakat Darülfünun dahi, Türk İnkılâbına dair on seneden beri henüz tek sayfa telif etmemiştir." Burhan Asaf Belge de Darülfünun'un Türk Tarih Tezi'ne karşı ilgisizlik ve bilimsel yetersizlik içinde olmasının yanısıra onuncu yılına girmek üzere olan Türk

\footnotetext{
"Şevket S. Aydemir, Inkılâp ve Kadro, 4. Baskı, İstanbul, Remzi Kitabevi, 1990, s.2732 .

${ }^{12}$ Burhan Asaf Belge, "Inkılâbımızın Sesi”, Kadro, Nu.I/11 (İkinci Teşrin 1932) s.37.

${ }^{13}$ Y. K. Karaosmanoğlu, Zoraki Diplomat, 2. Baskı, Ankara, Bilgi Yayınevi, 1967, s.26.

${ }^{14}$ Falih Rıfk1 (Atay), "Darülfünun”, Cumhuriyet, 23 Temmuz 1932, s.3. Darülfünun bir ilân yayınlayarak, "Gazi Mustafa Kemal Mükâfatı" adıyla düzenlenmiș olan 1500 lira ödüllü yarışmaya katılacak eserlerin kabule başlandığını ve ödülün 1932 Cumhuriyet Bayramından bir gün önce yarışmayı kazanan eserin yazarına verileceğini duyurur. Cumhuriyet, 27 Temmuz 1932, s.4. Bu ödülün hangi esere ve kime verildiğine veya verilip verilmediğine ilişkin bir bilgiye ulaşamadık.
} 
İnkılâbı'nın çeşitli yönlerinin üniversite mensupları nezdinde yankı bulmamasının dikkat çekici bir durum olduğunu belirtiyordu ${ }^{15}$.

Yukarıda da görüldüğü üzere, Türk İnkılâbı Tarihi'nin başlangıcı hakkında bir fikir birliğinin olmadığı anlaşılmaktadır. Bazıları bu konuda 1919'u, bazıları 1920'yi, bazıları da 1923 yılmı temel almakta, fakat bu fikirlerini açıklayan ve destekleyen dayanaklar ve kanıtlar ortaya koymayı ihmal etmektedirler. Gerçekte, Türk İnkılâbı, 1923 ile birlikte gerçek mecrasına girmiştir. Ki, ayrıca üzerinde durulması gereken gayet önemli bir konudur.

Reşit Galip, Maarif Vekili olduktan sonra Bakanlık bünyesinde bir “İnkılap Terbiyesi Komisyonu” oluşturmuştur ${ }^{16}$. Türk İnkılâbı Enstitüsü’nün kuruluş hazırlıkları da Maarif Vekili Reşit Galip'in başkanlığında Talim ve Terbiye Reisi İhsan Sungu, Basın-Yayından bir temsilci (?) ile Ankara Kız Lisesi'nden Tarih ve Yurtbilgisi Öğretmeni Afet İnan'dan oluşan bir komisyon tarafından yürütülmüştür. Bu konular Atatürk'ün yakın çevresinde de tartışılıyordu. Komisyonun hazırlayacağı rapora esas olacak hazırlıklar meyanında, İnkılâbın yapıcısı Atatürk'ün düșünceleri de alınmıștır. Türk İnkılâbı Enstitüsü hakkındaki düşüncelerini onaltı maddelik bir tasarı şeklinde hazırlayan Reşit Galip ${ }^{17}$, bu notlarında, Enstitünün "üniversitenin Zirvesi" olmasını istiyor ve Enstitüyü "üniversitenin terkip organı" şeklinde niteliyordu. Bu nedenle R. Galip, yalnız klasik öğretim yönteminin bir anlam ifade etmediğini, aynı zamanda Enstitünün etkin bir fonksiyonu olduğunu belirtiyor; bu bağlamda, "üniversite tahsili enstitüde kemale erer" diyor ve İnkılâb Enstitüsü bünyesinde İnkılâb Müzesi, İnkılâb Kütüphanesi, Akademik Seyahatler, Akademik Anketler, Akademik Polemik ve Neşriyat ile Halk Neşriyatı kollarının olmasını istiyordu ${ }^{18}$.

Türk İnkılâbı Enstitüsü, Üniversite Reformu çalıșmaları sırasında İstanbul Üniversitesi ile birlikte, 31 Temmuz 1933'te kurulmuştur. Reşit Galip, Üniversite Reformu hakkında 31 Temmuz 1933'te Anadolu Ajansı'na verdiği demeçte, İstanbul Üniversitesi'nin Tıp, Hukuk, Fen ve Edebiyat Fakültelerinden oluştuğunu, İlahiyat Fakültesi'nin İslam Tetkikleri Enstitüsü şeklini aldığını ve bundan başka üniversitede yedi enstitü bulunduğunu açıklamıştır: Türk İnkılâbı Enstitüsü, Milli İktisat ve İçtimaiyat Enstitüsü, Türkiyat Enstitüsü, Coğrafya Enstitüsü, Morfoloji Enstitüsü, Kimya Enstitüsü ve Elektro-Mekanik Enstitüsü. Bu enstitülerin bilimsel araştırmaların verimli merkezleri olacağını, üniversitenin en esaslı vasfının 48

${ }^{15}$ Burhan Asaf (Belge), "Arkada Kalan Darülfünun”, Kadro, Nu.I/8 (Ağustos 1932), s.47-

${ }^{16}$ Hakimivet-i Milliye. 19 Haziran 1933. s.1: Cumhurivet, 19 Haziran 1933, s.2.

${ }^{17}$ Afet İnan, Atatürk Hakkinda Hattralar ve Belgeler, 2. Baskı. Ankara, Kültür Yayınları. 1968. s.209-212.

${ }^{18}$ Ahmet Şevket Elman, Dr. Reşit Galip (1892-1934), Ankara, Yeni Matbaa, 1953. s.163166. R. Galip, söz konusu notlarında “Türk İnkılâp Enstitüsü” ismini kullanmıştır. 
milliciliği ve inkılâpçıllı̆̆ olduğunu, bu amaçla millî tarih için yeni kürsüler oluşturulduğunu ve Türk İnkılâbı ideolojisini yeni üniversitenin işleyeceğini, bu maksatla Türk İnkılâbı Enstitüsü kurulduğunu belirten R. Galip, Türk İnkılâbı Enstitüsü'nün ve diğer enstitülerin faaliyet programlarının ayrıca yayınlanacağını açıklamıştır ${ }^{19}$.

Darülfünûn'dan Üniversite'ye geçişte İstanbul Üniversitesi'nin ilk rektörü olan Neşet Ömer İrdelp'in, Maarif Vekaleti'ne gönderdiği bir mektupta, Türk İnkılâbı derslerinin, Maarif Vekili Reşit Galip tarafından verilmesine ilişkin bir telgrafı, 3 Ağustos 1933 tarihli gazetelerde yayınlanmıştır. R. Galip, Neşet Ömer'in söz konusu telgrafına 6 Ağustos tarihli yanıtında öneriyi kabul ettiğini belirtmiştir. Ancak bundan sonra, 10 Ağustos'ta Edebiyat Fakültesi Dekanı Fuat Köprülü ile Rektör Neşet Ömer İrdelp, 11 Ağustos'ta da Tıp ve Hukuk Fakülteleri dekanları istifa etmişlerdir. 14 Ağustos'ta ise Reşit Galip'in Maarif Vekilliğinden istifa etmesi üzerine söz konusu istifalar geri alınmıştır ${ }^{20}$. Atatürk'ün yakın çevresinde yankılar bulan bu istifaların asıl nedeni, R. Galip'in İnkılâp Tarihi derslerini inkılâbın önderi Atatürk'ten habersiz düzenlemek istemesi ve Atatürk'ün buna tepki göstermesidir.

Reşit Galip, Atatürk'ün haberi olmaksızın ve üstelik Onun isteğiymiş gibi göstererek, Rektör Neşet Ömer'e Türk İnkılâbı kürsüsü reisliğinin kendisine verilmesini istemesi üzerine; Rektör Neşet Ömer İrdlip, söz konusu derslerin Reşit Galip'e verildiğini açıklamıştır. Bunun üzerine Atatürk, R. Galip'e "inkılâp profesörlüğünü yapmaya kadir olmadığını" belirtmiş ve Maarif Vekilliğini bırakmasının uygun olacağını söylemiştir ${ }^{21}$. Maarif Vekilliğine, vekâleten 14 Ağustos'ta Dr. Refik Saydam atanmış, Cumhuriyetin onuncu yilına girerken, 27 Ekim 1933'te ise Refik Saydam'n yerine Yusuf Hikmet Bayur asaleten Maarif Vekili olmuştur. Bayur'un daha önce Cumhurbaşkanlı̆̆ Üniversite ile birlikte Enstitüye ve İnkılâp derslerine verdiği öneme de bir işaret sayılabilir.

Türk İnkılâbı Enstitüsü kurulduktan sonra Enstitü akademik kadrosuna Mükrimin Halil Yinanç, Hilmi Ziya Ülken, Akdes Nimet Kurat, Enver Ziya Karal, Nizamettin Ali, Ziyaeddin Fahri Fındıkoğlu, Ahmet Akif Beyler atandılar. Bu isimlerin sonraki süreçte Enstitüde etkin olamadıkları görülmektedir. Bu dersleri Hukuk Fakültesi'nde verenlere yardımcı olanlardan Hifzı Veldet, Yavuz Abadan gibi doçentler ise sonraki dönemde bu konuda yetkin birer şahsiyet olmuşlardır. Hukuk Fakültesi, Üniversitenin

${ }^{19}$ A.g.e., s.155-163. Üniversite Reformu çerçevesinde bir “İnkılâp Enstitüsü” kurulacağı 20 Haziran 1933'te haber olmuştur. "Inkılâp Enstitüsü”, Cumhuriyet, 21 Haziran 1933, s.1.

2) Mete Tunçay-Haldun Özden, "1933 Darülfünun Tasfiyesi veya Bir Tek-Parti Politikacasının Önlenemez Yükselişi ve Düşüşü“”, Tarih ve Toplum, Nu.Il/10 (Ekim 1984), s.15.

${ }^{21}$ Ali Arslan, Darülfünun'dan Üniversite'ye, İstanbul, 1995, s.369-371. 
Genel Türk Tarihi kürsüsünde Türk Tarihi Tetkik Cemiyeti (sonra Türk Tarih Kurumu) başkanı Yusuf Akçura ile Cemiyet azasından Mehmet Şemsettin Günaltay, Yusuf Hikmet Bayur, Sadri Maksudî Arsal'ın belirli zamanlarda İ́stanbul'a gelerek ders vermelerine karar verildi ${ }^{22}$. Bu da İnkılâp Enstitüsü'nün Yakınçağ Türkiye Araştırmaları için önemli bir kurum olarak tasarlandığını göstermektedir. Fakat sonraki gelişmeler Enstitüyü bir tedrisat merkezi haline getirmiştir.

Türk İnkılâbı'nın kuramsal boyutlarını ortaya koyma çalışmalarının çoğunlukla Kadro hareketi ile gündeme geldiği varsayılır. Hükümetin de bu yönde çalışmalarda bulunduğu, 1934'te başlatılan Türk İnkılâp Tarihi Dersleri'nde açıkça görülmektedir. Bu derslerin okutulmaya başlanmasından bir y1l kadar sonra CHP'nin 9 May1s 1935 'te toplanan Dördüncü Kurultayı'nda altı ilke, "Kemalizm Prensipleri” olarak tanımlanmıştır. Mayıs 1935 'ten itibaren de bu ideolojiyi açılayan çeşitli eserler yayınlanmaya başlamıştır. Atatürk, CHP'nin 1935 Kurultayı'nı açış konuşmasında “Türk genel devrimi" ${ }^{23}$ deyimini kullanmıștır. Yukarıda verdiğimiz örneklerden de anlaşılacağı üzere, Atatürk önderliğindeki İnkılâp hareketini adlandırmak konusunda ortak bir görüş bulunmamaktadır. Bunun nedeninin Atatürk'ün, önderi olduğu harekete bir ad verilmesinin henüz zamanı gelmediği kanısından kaynaklandığı söylenebilir. Atatürk'ün düşünce arkadaşları tarafından verilen Türk İnkılâbı Tarihi derslerinde de ortak bir isim kullanılmaması bunun bir diğer göstergesidir.

İstanbul Üniversitesi Türk İnkılâp Tarihi Enstitüsü'ndeki dersler, 4 Mart 1934 Pazartesi günü saat 17.30'da Maarif Vekili Yusuf Hikmet Bayur'un dersiyle başlamıştır. Bu ilk dersinde okutacağı Türk İnkılâbı Tarihi dersinin çerçevesini çizen ve ana hatlarıyla İnkılâbın gelişimini açıklayan Hikmet Bayur, Türk İnkılâbı'nın 1934'e kadar gelişimini şu üç evreye ayırmıştır: Askeri ve Siyasi Kısım: İşgalci devletlere ve Osmanlı hükümetine karşı bağımsızlık mücadelesi; Çağdaşlaşma (Hukuk) Kısmı: Hükümetin Ortaçağ biçiminden modern devlete geçmesi; İktisadi Kısım: Esnaflıktan ve ilkel sanayiden modern sanayiye geçilmesi. Bundan sonra, derslerin de bu taksime uygun şekilde verileceğini açıklayan Yusuf Hikmet Bayur'a göre, büyük ve kapsamlı bir değişimi ifade eden İnkılâbı, bir kişinin anlatması olanaksızdır; dersleri, aktif şekilde İnkılâbın içinde bulunmuş olanlar anlatmalıdır ${ }^{24}$.

Hikmet Bayur, ikinci dersini 5 Mart 1934'te verdikten sonra diğer profesörler de Türk İnkılâbı derslerini okutmaya başlamıştır. Mart 1934'te

\footnotetext{
${ }^{22}$ Saadet Tekin, "Dr. Reşit Galip ve Üniversite Reformu”, Çağdaş Türkiye Tarihi Araşturmalar Dergisi, Nu.I/2 (1992), s.208-210.

${ }^{23}$ Atatürk'ün Söylev ve Demeçleri, C.II. s.398.

${ }^{24}$ "Inkılap Enstitüsü'nde Illk Ders Verildi”, Hakimiyet-i Milliye, 5 Mart 1934, s.1, 5.
} 
Mahmut Esat Bozkurt, 11 Mart 1934'te Yusuf Kemal Tengirşenk ilk derslerini vermiștir ${ }^{25}$. Bu sıralarda, Mart 1934'te Ankara Hukuk Fakültesi'nde de bir Türk İnkılâbı Kürsüsü kurulmuştur ${ }^{26}$. Ankara'da ise ilk Türk İnkılâbı Tarihi dersini, 20 Mart 1934'te Ankara Halkevi'nde Başbakan İsmet İnönü vermiştir. Bunlardan başka, Eylül 1934'ten itibaren İzmir Halkevi'nde halka yönelik Türk İnkılâbı dersleri verilmeye başlanmıştır. İzmir'deki bu dersleri Mahmut Esat Bozkurt'un yanısıra Asım Kültür, Ferit Tok, Muallim Mithat, Hakkı Baha, Mustafa Münir gibi İzmir'in tanınmıș aydınları veriyordu ${ }^{27}$. Başbakan İsmet İnönü'nün 20 Mart 1934'te verdiğgi "Türk İnkılâbı" başlıklı konferansı, söz konusu derslerin niteliğini ve çerçevesini belirleyici bir içeriktedir.

Bu konferansında İsmet İnönü, "Türk İnkılâbı Türk milletinin kurtuluş savaşıdır" diyor, bu nedenle İnkılâp atılımlarının Osmanlı ıslahat, hatta ihtilâl hareketlerinin devamı ve uzantısı olmadığını belirtiyor ve şöyle devam ediyordu: "Türk inkılâbı, Türk kurtuluş davası olarak ecnebi istilâsına karşı, bir dereceye kadar sade ve askerî-siyasî mahiyette başlar. Ve fakat daha ilk anında Osmanlı nizamına karşı bünyevî-millî ve siyasî inkılâplara girer. Millet varlığını anlayışta, esaslı farkı ise, kuvvet önünde imparatorluğun teslimiyetine karşı Türk İnkılâbının ret ve mücadele kararında bulacaksınız." İnönü, bu mücadelenin önemli aşamalarını bu dersleri verecek profesörlerin anlatacağını belirtmiş, İnkılâbın incelenmesinde izlenecek yöntemi ise şöyle açıklamıştır ${ }^{28}$ : "Size Türk İnkılâbı'nın daimî seyrini mütalaa ederken onun ihtiyaçtan doğan ve daima ihtiyaçla beraber yürüyen mahiyetine dikkatinizi celp etmeliyim. Bir takım nazarî prensipleri ilk anda birden ifade, ilan eden ve onları tatbike çalışan usul yerine bizde, millî ülküyü ve büyük ana hatları gözde tutan ve tatbikatta her lüzum karşısında, müteakiben, fakat durmadan, tedbirini bulan, usul carî olmuştur..."

Konferansında İnönü, "Türk İnkılâbı davası" dediği hareketin başlıca iki yönde oluştuğunu açıklamıştır. Birincisi, devrimlerden hiçbir şekilde ödün vermemek ve geriye dönüş yapmamaktır. İkincisi, Türk milletinin yüksek bir düzeye varması yönünde ilerlemek yolunda yeni ihtiyaçların karşılanması ve her engelin ortadan kaldırılmasıdır. İnkılâbın önderi Atatürk, İstanbul Üniversitesi Edebiyat Fakültesi bünyesinde Türk İnkılâbı Enstitüsü'nü kurarken, bu enstitünün Türkiye'nin yakın dönemini inceleyen bir merkez olmasını istemiş ve İnkılâp derslerini verenlerin çalışmalarının önemli ürünler vereceğini düşünmüş. Bu nedenle Atatürk, Türk İnkılâbı Tarihi

25 “Inkılap Enstitüsü’nde İkinci Ders", Hakimiyet-i Milliye, 6 Mart 1934, s.1, 3; "İhtilâlin Felsefesi" Hakimiyet-i Milliye, 9 Mart 1934, s.3; "Inkılâp Enstitüsü”. Hakimiyet-i Milliye, 12 Mart 1934, s.3.

${ }^{26}$ Şerafettin Turan, İsmet Inönü. Yaşamı, Dönemi ve Kişiliği, Ankara, Kültür Bakanlığı, 2000, s.152.

${ }^{27}$ Hakkı Uyar, "Türk Devrimi'ni Teorikleştirme Çabaları: Mahmut Esat Bozkurt Örneği I", Tarih ve Toplum, Nu.XX/119 (Kasım 1993), s.12.

28 “İnkılâp Kürsüsünde İsmet Paşanın Dersi”, Ülkü, Nu.III/14 (Nisan 1934), s.184-190. 
incelemelerinde yeni bir gelișmeden haberdar edildikçe, bu çalışmalarla daha yakından ilgilenir ve konuyu aydınlatıcı açıklamalar yaparmış. Yusuf Hikmet Bayur, İnkılâp hareketine, Osmanlı islahat hareketlerinden ayırmak amacıyla, "Atatürk İnkılâbı" adının verilmek istendiğini fakat Atatürk'ün bunu kabul etmediğini belirtmektedir. Bayur'a göre Atatürk, bütün çalışmalarında ulusu esas aldığından, İnkılâb'a "Türk İnkılâbı”, derslere de "Türk İnkılâbı Tarihi" denmesini istemiştir ${ }^{29}$.

Türk İnkılâbı ders notlarından oluşan "Türkiye Devletinin Dış Siyasası" başlıklı kitabında Hikmet Bayur, Dış Politika Tarihini şu dört kısımda incelemiştir: Giriş, Ankara'daki Milli Hükümetin Dış Siyaseti, Lozan Konferansı ve Lozan sonrası. Derslerine Birinci Dünya Savaşı öncesinde Osmanlı İmparatorluğu'nun genel durumunu ve Birinci Dünya Savaşı'ndaki gelişmeleri ana hatlarıyla anlatarak başlayan Bayur, Türk İnkılâbı'nın başlaması açısından 30 Ekim 1918 tarihli Mondros Mütarekesi ile onu izleyen gelişmeleri ayrıca incelemiştir. Bayur'un üzerinde durduğu asıl konu, TBMM Hükümeti'nin kurulmasından sonraki gelişmelerdir. "Sèvres" konusuna özel önem veren Bayur, Lozan Antlaşması'nın öneminin kavranabilmesi için Sèvres Anlaşması'nın iyi bilinmesi gerektiğini şöyle belirtir ${ }^{30}$ : "Milli Mücadelenin safhaları ve onunla istihsal olunan haricî siyasete ait netice yani Lozan muahedesi tetkik edilirken işe nereden başlanıldığı hiçbir vakit gëzden kaçırılmamalıdır. Ve bu mücadele yapılmasa idi veyahut muvaffakiyetle neticelenmeseydi Türk milletinin ne vaziyete düşeceği ve Sèvres muahedesile nasıl imha edileceği daima hatırda olmalıdır."

Yusuf Hikmet Bayur, Ankara Hükümeti'nin dış politikası açısından Lozan Barış Antlaşması'na merkezi bir konum vermiş ve gelişmeleri, Lozan'dan önce ve Lozan'dan sonra olmak üzere iki döneme ayırarak anlatmıştır. Lozan Barış Antlaşması'nın, esasları 1919'da Mustafa Kemal tarafindan belirlenen ve 1920'de Osmanlı Mebuslar Meclisi'nde kabul olunan Misak-1 Millî'nin gerçekleşmesi ve bütün dünyaya tanıtılması olduğunu belirten Bayur, bu anlaşmanın birçok dersleri de içerdiğini belirterek, bunları şu üç başlık altında açıklamıştır: Türklerin sarsılmaz iradesini Türklüğe ve bütün dünyaya bir kere daha kanıtlaması, Atatürk'ün İnkılâp hareketinin yolunu açmış olması ve son olarak, ulusal amaçların gerçekleşmesinin başkasıının yardımıyla değil, ancak ulusun kendisi tarafından yapılabileceği düşüncesinin anlaşılmış olması. Bayur'a göre

\footnotetext{
${ }^{29}$ Yusuf Hikmet Bayur, Türk Inkılâbı Tarihi, C.I. Ankara, TTK Yayınlan, 1940, s.IX-XI. Bu eser, Türk Tarih Kurumu'nun "Türk Tarihinin Ana Hatları" serisi çerçevesinde yayınlanmıştır. Bayur'un bu konuda uzun zamandır çalışmakta olduğu izlenimini veren bu eser, ilk olarak 1940'da bir cilt halinde, $1943^{\prime}$ te ikinci cildi iki kitap halinde çıkmış ve 1951 'den itibaren ikinci cildin üçüncü kısmı ve devamı yayınlanmıştır.

${ }^{30}$ Hikmet Bayur, Türkiye Devleti ${ }^{\prime}$ in Dış Siyasası, Ankara, TTK Yayınlanı, 1973, s.62.
} 
Cumhuriyet hükümetinin en önemli bașarılarından biri de, Türkiye'nin bütün komşularıyla sınır sorununu çözmüş olmasıdır ${ }^{31}$.

Hikmet Bayur'un “Türkiye Devletinin Dış Siyasası" başlıklı kitabı, 1935 'te İstanbul Üniversitesi Türk İnkılâbı Enstitüsü'nün ilk yayını olarak çıkmıştır. Bayur, söz konusu eserinin yeni baskısını hazırlarken dönemin Dışişleri Bakanı Tevfik Rüştü Aras'ın da görüşlerini almış ve 1936 Montreaux Boğazlar Sözleşmesi'ni de eklemiștir. Bu eserin, 1938'de Türk İnkılâbı Enstitüsü yayınları arasında ikinci baskısı yayınlanmıştır. Aynı yıl "Türk Tarihinin Ana Hatları" serisinde "Yeni Türkiye Devletinin Haricî Siyaseti” adıyla yayınlanmıștır. Hikmet Bayur'un sözü edilen eseri aynı zamanda Atatürk önderliğindeki tarih çalıșmaları kapsamında yapılmıș bir çalışmadır. Türk İnkılâbı Enstitüsü'nün ikinci yayını ise, 1939'da iki cilt halinde yayınlanan Alman Türkoloğu Gotthard Jaeschke'nin "Türk İnkılâbı Tarihi Kronolojisi (1918-1923)" adlı eseridir. Bu eser, Darülfünun Divanı'nın Türkiye Cumhuriyeti Tarihi yazımı konusunda açtığı bir yarıșmaya sunulmak üzere hazırlanmıs ve 1930 ortalarında üniversite yönetimine takdim edilmişti.

Türk İnkılâp Tarihi dersi veren bir diğer kiși Mahmut Esat Bozkurt'tur. Hakkı Uyar'a göre, Mahmut Esat'ın Türk İnkılâbı dersleri için hazırladığı "Atatürk İhtilâli" adlı eseri, içerik ve kapsam yönünden diğerlerine oranla daha üstündür ${ }^{32}$. Sina Akşin ise, M. E. Bozkurt ile Recep Peker arasında İnkılâbın incelenmesinde ve anlatımında bir işbölümü yapıldığını belirtmekte; Peker'in "kuru sayllabilecek" üslubuna karşıllık, Bozkurt'un heyecanlı ve coşkulu bir üslubu olduğunu ve Bozkurt'un kitabının içeriği gibi üslubunun da ihtilâlci olduğunu açıklamaktadır. S. Akşin'e göre Bozkurt, devrimlerde ekonomik etkene özel önem vermektedir ${ }^{33}$. Bozkurt'un İnkılâp derslerinin diğerlerine üstünlüğü, onun Kurtuluş Savaşı yıllarından (1921) itibaren bu konuyla ciddi şekilde ilgilenmiş olmasından kaynaklanmaktadır ${ }^{34}$. İnkılâp dersleri notlarından oluşan "Atatürk İhtilâli" adlı eserinde M. E. Bozkurt, "İhtilâl" kavramını, "bir şeyin esasından değişerek, yerine yepyenisinin konulmasıdır" şeklinde tanımlamaktadır ${ }^{35}$

Recep Peker ise, Türk İnkılâbı Tarihi derslerinde, İnkılâbın dünyadaki siyasal partiler ve sistemler karşısındaki konumunu anlatmıştır. Recep Peker derslerinin amacını, "İnkılab devrini yaşamış, o devri hazırlamış insanların ruhunda en kuvvetli ileri hareket unsuru olan sıcaklığg ve heyecanı, ulusal çalışma hayatına çıkacak olan genç Türk nesillerine, yeni unsura aşılamaktır

\footnotetext{
${ }^{31}$ A.g.e., s.148-149, 176

${ }^{32}$ Uyar, "Türk Devrimi'ni Teorikleştirme Çabalan I", s.15.

${ }^{33}$ Sina Akşin, "Bozkurt ve Peker'in Devrim Tarihi Ders Kitapları”, Çağdaş Türkiye Tarihi Araştırmaları Dergisi, Nu.I/4-5 (1994-1995), s.233-235.

"Ut Uyar, "Türk Devrimi'ni Teorikleştirme Çabaları I", s.9-12.

${ }^{35}$ Mahmut Esat Bozkkurt, Atatürk Ihtilali; 3. Baskı. İstanbul, Kaynak Yayınları, 1995. s.163.
} 
ve onları yaşadığımız inkılap prensiplerile yetiștirip vazifeye hazırlamaktır." şeklinde açıklamıştır. Bu nedenle Peker, olayları kronolojik şekilde anlatan klasik tarzda değil, söz konusu amaca ulaştıracak bir yöntemle anlatmayı tercih etmiştir. Peker, inkılabın, bir sosyal bünyenin eski zararlı yönlerini söküp, onların yerine yeni ve ileri nitelikli olanları koymak olduğunu belirtmiştir. Peker'e göre bu yeniliklerin devamının sağlanması için bir sistem kurmak ve işletmek, devrimin zorunlu koşuludur; Türk inkılabçıları, yalnızca yeni hayat koşullarına uyum sağlamış bir toplum oluşturmayı değil, İnkılabı bilinçli bir şekilde kökleştirmeyi de hedeflemektedir ${ }^{36}$. Peker'e göre İnkılab'ın en önemli tamamlayıcısı İstiklal'dir; İnkılabsız İstiklal, İstiklalsiz İnkılab olmaz, olamaz ${ }^{37}$.

Yusuf Kemal Tengirşenk'in 1934-1935 öğretim yılında Ankara ve İstanbul'da bulunan fakülte ve yüksekokullarda verdiği "Türk İnkılâbı Dersleri" ise diğerlerine oranla hazırlıksız ve yüzeysel bir görünüm arzetmektedir. Tengirşenk'in on dersten oluşan kitabı, gerek kuramsal gerek içerik gerekse kapsam yönünden İnkılâbın ekonomik boyutunu gereğince irdelemiş olmaktan uzaktır. Örneğin Tengirşenk, "Bu dersin mevzuu nedir?, Hangi oluşları araştıracağız?" sorularını, "Değişme oluşlarını araştıracağız. Var mıdır? Evet vardır. Gözümüzün önündedir.” şeklinde yanıtlamıștır. Tengirşenk, "Dış oluşlarla beraber iç oluşları da tetkik edeceğiz"38 demekle birlikte, Osmanl1-Avrupa iktisadi ilişkilerini veya Türkiye ekonomisinde kapitülasyonların yerini layıkıyla irdele(ye)memiștir. Bu nedenlerle, Türk İnkılâbı Enstitüsü'nün yalnızca Hikmet Bayur'un eserini yayınlaması anlamlıdır ${ }^{39}$. Bununla birlikte, Türk İnkılâbı Tarihi derslerinin, Yusuf Kemal'i ekonomik konularda ciddi çalı̧̧malara yönelttiği anlaşılmaktadır. Tanzimat'ın yüzüncü yılı dolayısıyla yayınlanan "Tanzimat" adlı eserde, ciddi bir inceleme ürünü olduğu anlaşılan "Tanzimat Devrinde Osmanlı Devleti'nin Haricî Ticaret Siyaseti" başlıklı makalesi bunun bir göstergesidir.

Türk İnkılâbı Tarihi'nin tetkikinde ve tedrisinde takip edilen yöntem konusunda da bir fikir birliğinin oluşmadığı anlaşılmaktadır. Fakat üzerinde durulan en önemli ortak noktanın Thomas Carlyle'nin "Büyük Adamlar" nazariyesi olduğu görülmektedir. Bu noktayı dönemin yetkin bir kültür adamı olan Mehmet Fuat Köprülü 1936'da yazdığı bir Önsöz'de şöyle vurgulamıștır" : "Atatürk, olayların yarattığı bir önder değil, olayları yaratan

\footnotetext{
${ }^{36}$ Recep Peker, Inkılab Dersleri Notları, Ankara, Ulus Basımevi, 1935, s.1-8.

${ }^{37}$ A.g.e., s.13-14.

${ }^{38}$ Yusuf Kemal Tengirşenk, Türk Inkılâbı Dersleri, İstanbul, Resimli Ay Basımevi, 1935 , s.3-5.

${ }^{39} \mathrm{Bu}$ derslerin notları, Yusuf Hikmet Bayur'un dışındakiler, Prof.Dr. Oktay Aslanapa tarafından yakın zamanlarda toplu olarak yayınlanmıştır. Bunun için bkz: İlk Inkılâp Tarihi Ders Notları, İstanbul, 1997.

t0 Tekinalp, Kemalizm, sad. Çetin Yetkin, İstanbul, Toplumsal Dönüşüm Yayınları, 1998. s.25.
} 
bir baştır." Sonraki yıllarda bazı aydın ve tarihçilerin Türk İnkılâbı'na Atatürk Devrimi adını vermelerinin nedeni de esas olarak bu yaklaşımdır. Atatürk ise Türk İnkılâbı deyimini kullanmıștır. Doğrusu da budur; çünkü devrimler, devrimci bir kadronun başında bulunan bir liderin şahsında somutlaşmakla birlikte, esas olarak, halka dayanan ve çoğu zaman "halka rağmen, halk için" mantığı ile yapılan toplumsal bir harekettir ${ }^{41}$.

Sonuç olarak, 1933 Üniversite Reformu çerçevesinde, İstanbul Üniversitesi bünyesinde kurulan Türk İnkılâp Tarihi Enstitüsü, Yakınçağ Türkiye Tarihi araştırmaları alanında akademik-bilimsel bir gelenek ortaya koyamamış; fakat dönemin ideolojik ve siyasal bir ihtiyacını karşılamak, yeni nesli İ̉nkılâp ruhuyla donatmak ve rejimine sahip çıkan bir cumhuriyet kuşağı yetiştirmenin yanısıra, Türk İnkılâbı'nı incelemek ve bunun sonuçlarını aydın kesime ve kamuoyuna anlatmak ve aktarmak amacıyla kurulmuş işlevsel bir kurumdur. Kuruluşunun yetmiş beşinci yılına yaklaştığımız İstanbul'daki bu kıdemli Enstitü ile birlikte Ankara'daki kardeşini de Yakınçağ Türkiye Tarihi araştırmaları alanında ortaya koyduğu araştırmalarla etraflı şekilde inceleme konusu etmenin zamanı gelmiştir.

\footnotetext{
${ }^{41}$ Bir kavram ve hareket olarak "Devrim" deyimi hakkında yetkin bir açıklama için bkz: Taner Timur. Türk Devrimi ve Sonrası, 5. Baskı. Ankara, İmge Kitabevi, 2001, s.302 vd.
} 